\title{
INVESTIGATION OF THE PHYSICAL SUITABILITY OF EMPLOYEES OF THE MINISTRY OF INTERIOR
}

\author{
Yoni Petrovska \\ National Sports Academy "Vassil Levski” (Bulgaria)
}

\begin{abstract}
The professional activity of the employees in the Special Home for Temporary Accommodation of Foreigners at the Migration Directorate is closely related to their physical, combat, applied preparation, etc. Priority among specialized knowledge and skills is given to physical fitness. The characteristics of the activity show that the successful completion of the various tasks requires the performers to have appropriate motor skills. They are demonstrated as a system of meaningful and purposeful simple or complex movements, which are evaluated based on specific actions. Due to the specifics of the tasks to be solved, professional preparation is necessary. The purpose of the study is to establish the physical fitness of employees in junior executive positions. To assess and establish the level of physical fitness, a sports pedagogical test was conducted with 90 employees with an average age of 42.8 years. The attached test battery includes four tests approved by the Ministry of Interior. Analysis of motor test results in terms of speed, coordination, and endurance are lower in the assessment. This fact gives us reason to believe that in practice not enough purposeful work is done to develop the strength of the lower limbs and endurance.
\end{abstract}

Keywords: physical fitness; evaluation; junior executive position

\section{Introduction}

The Migration Directorate is a structure of the Ministry of Interior regulating migration processes and administrative control over the residence of foreigners in the Republic of Bulgaria, counteracting illegal migration on the territory of the Republic of Bulgaria and performing administrative services to citizens of the European Union, to citizens of countries under the Agreement on the European Economic Area, to citizens of the Swiss Confederation, as well as their family members, according to the Law on entry and residence in and departure from the Republic of Bulgaria to citizens of the European Union who are not citizens of Bulgaria and their family members. (Rules on the structure and activity of the Ministry of Interior 2017). The Migration Directorate carries out activities on forcible accommodation in special homes for temporary accommodation of foreigners (SHTAF) 
for persons for whom an order for return or expulsion has been issued. The management and security of the SHTAF is carried out by the Migration Directorate. (Rules on the structure and activity of the Ministry of Interior 2017).

The professional activity of employees working in SHTAF (Special Homes for Temporary Accommodation of Foreigners) is closely related to their physical, combat, applied, and other preparation. According to the Law on the Ministry of Interior (2018), they must meet specific requirements for age, education, physical fitness, and psychological fitness. The legislation of the Ministry of Interior contains the specialized methodology which determines the conditions and procedure for planning, organizing, conducting, controlling, and reporting the physical training of the employees of the Ministry of Interior (Specialized Methodology 2007).

Physical fitness is a priority in the specialized knowledge and skills. It includes three main components - physical health, physical development, and physical performance.

The activities of police officers, especially those in specialized units, are carried out in conditions of danger to their lives. It is not uncommon for them while performing their tasks to face counteractions and refusal to comply with a lawful order (Yordanov 2014a). Circumstances often require quick and adequate response to emerging combat missions. Their successful implementation requires constant improvement of combat and applied training (Yordanov 2014b).

The main tasks of the unit are related to the access control regime, as well as to the protection of illegally staying foreigners, forcibly accommodated in SHTAF, according to an order for organization of patrol activity for security of SHTAF. (Order 5364z-46/2021) This requires constant improvement of their professional qualification. Employees must be able to integrate internationally to effectively counter these dangers (Bachev \& Georgiev 2004). Along with all knowledge, psychophysical training, according to Kachev, 2015, remains a leading factor in the formation of the preventive attitude to the actions towards emerging problems in terms of security and public order in all spheres of public life.

The characteristics of the activity show that the successful completion of the various tasks requires the performers to have appropriate motor skills. They manifest themselves in the form of a system of meaningful, purposeful, simple, and complex movements. They are assessed based on specific actions. According to the specifics of the tasks to be solved, they must be professionally prepared. To achieve a high level of professional training, systematic and purposeful training is needed. According to Tz. Zhelyazkov, (2001), this transfer of the overall motor activity of the individual is possible to be realized only due to the motor qualities strength, speed, endurance, and flexibility. They find external manifestation in the form of various combinations in terms of time, space, and effort, i.e., materialized in special skills and habits.

The purpose of the study is to determine the physical fitness of employees holding the position of junior police inspector. 
To solve our goal, we set the following tasks:

1. Examination of the physical fitness of employees.

2. Assessment of the level of special physical fitness.

3. Establishing the effectiveness of the approved specific training on motor skills.

\section{Methodology}

To assess and establish the level of special physical fitness, a sports pedagogical test was conducted with 90 employees with an average age of 42.8, divided into two groups, as the test battery was defined by gender -64 men at an average age of 43.8 years and 26 women at an average age of 41.8 years.

For the needs of the study, the employees are subjected to a specialized test battery for control of physical training, approved by the Ministry of Interior (Ordinance 2014).

Employees are tested with the following motor tests:

For the men:

- Folding and unfolding the arms in support position (pcs.);

- Lifting the body from lying on the back to a sitting position (pcs.);

- Standing long jump (cm);

- Figure 8 running drill (sec.);

- 800-metre run (min.).

For the women:

- Lifting the body from lying on the back to a sitting position (pcs.);

- Standing long jump (cm);

- Figure 8 running drill (sec.);

- 800-metre run (min.).

The obtained data were subjected to mathematical and statistical processing with Microsoft Excel.

\section{Results and analysis}

According to the current methodology, we have analysed the main motor qualities strength, speed, coordination, and endurance. The physical training required by the nature of the work is at a high level. The evaluation results are either 'performed' or 'not performed'.

For all indicators we observe the following percentage distribution of evaluations for all surveyed persons: for all indicators the surveyed men and women have achieved the evaluation 'performed', i.e., the current state of physical qualities of employees is at the appropriate level required by the test battery of the Ministry of Interior.

Assessment, according to Slavova (2017), helps providing a systematic feedback on their own progress, understanding their own strengths and weaknesses, and also 
the reported assessment can be used to track progress in the overall process with guidelines for future studies and practical action. The obtained average data from the studied indicators of the two groups are shown in Table 1.

Table 1. Average values of the achievements by indicators

\begin{tabular}{|l|c|c|c|c|c|}
\hline Gender & $\begin{array}{c}\text { Folding and unfolding } \\
\text { the arms in support } \\
\text { position (pcs.) }\end{array}$ & $\begin{array}{c}\text { Lifting the body from } \\
\text { lying on the back to a } \\
\text { sitting position (pcs.) }\end{array}$ & $\begin{array}{c}\text { Standing } \\
\text { long jump } \\
\text { (cm) }\end{array}$ & $\begin{array}{c}\text { Figure 8 } \\
\text { running drill } \\
\text { (sec.) }\end{array}$ & $\begin{array}{c}800-\text { metre } \\
\text { run (min.) }\end{array}$ \\
\hline Men & 40.08 & 40.11 & 213.08 & 16.31 & 3.75 \\
\hline Women & - & 33.96 & 177.09 & 17.12 & 3.80 \\
\hline
\end{tabular}

Analysing and comparing the average data (Table 1) between the two groups, we found close and better achievements in male employees on some of the studied indicators, except for "800-metre run", where we found similar achievements. Considering that the requirements for men and women are different to meet the standards, as well as the fact that all employees have received the evaluation 'performed', we believe that their training is at the level required by the ministry.

Analysing and comparing the average data separately for each indicator of Table 1 we find that in the test "Folding and unfolding the arms in support position" in terms of muscle strength of the upper limbs, the male employees performed an average of 40.08 repetitions, i.e., the minimum number to cover the requirement (40) and to achieve the evaluation 'performed'.

In the "Lifting the body from lying on the back to a sitting position" test we found that male employees cover the requirement (40), and female employees have done an average of almost 2 repetitions above the regulatory requirements (32).

The state of the explosive force of the muscles of the lower limbs is essential for the successful overcoming of obstacles of various nature. To measure the explosive power of the lower limbs, we used the "Standing long jump" test, in which the average achievement of male employees is $213.08 \mathrm{~cm}$ - an average of $3 \mathrm{~cm}$ above the requirement (210), and female employees is $177.09 \mathrm{~cm}$ - an average of $2 \mathrm{~cm}$ above the minimum requirement (175).

The test for speed and coordination that we applied - "Figure 8 running drill", showed for all surveyed employees an average result of 0.43 seconds better than the one set in the requirements of the Ministry of Interior. For men, the average result is 0.49 seconds above the normative requirements (16.8), and for women $-0.38 \mathrm{sec}$ above the respective requirements (17.5).

Endurance is essential for all uniformed employees. Aerobic capacity is fundamental to their performance. The manifestation of this motor quality requires maximum mobilization for action in extreme conditions. We get information about their condition through the test "800-metre run". As demonstrated in Table 1 of the results obtained, male employees showed an average achievement of 0.25 minutes and female employees 
-0.20 minutes above the regulatory requirements (4.00). This test requires significant effort to successfully meet the standard. It should also be noted that they achieved a value with a minimal difference from the upper limit. In our opinion, work experience is the factor that influences the achievement and not age, which supports the opinion of some authors (Boyanov \& Yankova 2009; Yankova 2016).

In general, the physical fitness of employees meets the requirements. They have a good development of the strength of the muscles of the upper limbs according to the test "Folding and unfolding the arms in support position", but just as in "Lifting the body from lying on the back to a sitting position", "Standing long jump", "Figure 8 running drill", and "800-metre run" the evaluation as per these indicators is 'performed' according to the requirements of the Ministry of Interior, but the average achieved values are close to or equal to the upper limit. According to Yordanov, (2015) additional external and internal factors influence the effectiveness of professional activity. According to Panayotov et al. (2018), the employees of the Ministry of Interior define their level of special training as weak and at a low level due to their number of commitments. To fulfil their functional duties, it is necessary to improve the quality of physical and combat applied training. The idea is to train the lagging muscle groups as a priority (Panayotov 2018). The fact that sports training plays an important role is confirmed by the average achievements close to the upper limits. The declaration of a state of emergency on the entire territory of the Republic of Bulgaria because of the growing COVID-19 pandemic and the continuing epidemiological situation so far, adversely affects both the quality of individual training and their specialized training following the annual and topic plans approved by the director of the Migration Directorate.

\section{Conclusion}

The analysis of the results of the motor tests gives us reason to believe that the development of speed and dynamic strength endurance is closer to the upper limit compared to the evaluation of the other studied qualities. This fact gives us reason to believe that the methodology used in practice does not correspond to the requirements of the modern assessment system for physical fitness and training. When analysing the necessary qualities, the need for adequate further development of new forms and methods for improving the lagging physical qualities to be included in the special physical training of employees comes to the fore. All this, in our opinion, also requires that norms and assessment be updated through new standards, due to the fact that generations have a different biological status.

\section{NOTES}

1. Law on the Ministry of Interior, 2018. Amend. State Gazette (10)

2. Order 5364z-46, 2021. Regarding: Organisation of patrol activity for security of Specialized home for temporary accommodation of foreigners - Sofia (SHTAF Sofia) for 2021, p. 1. 
3. Ordinance No. 8121z-344, 2014 for employment as state employees in the Ministry of Interior, last amend. and suppl. SG issue 44/2019.

4. Rules on the structure and activity of the Ministry of Interior, 2014. In force since 22.07.2014. Adopted with Council of Ministers' Decree No. 207 dd. 18.07.2014. Last amend. and suppl. SG issue 33 dd. 25 April 2017.

5. Specialized Methodology on education and control of MoI employees on physical training, 2007. Reg. No.: I3-453/21.03.2007 of the MoI

\section{REFERENCES}

Bachev, V. \& Georgiev, P., 2004. Izsledvane na fizicheskata godnost na slujitelite v MVR kato vazmojnost za otcenka na sastoianieto i pri naselenito na Balgaria, Nacionalna sigurnost, fizisheska podgotovka, sport, NSA, $142-152$.

Boyanov, V. \& Yankova, N. 2009. Sravnitelen analiz i razlishia v individualnata podgotovka na kadetki, devoiki I jeni-tejkoatletki., Sport and science (2), 19.

Jeliazkov, Ts., 2001. Theory and methodology of sports training. Sofia.

Yordanov, S., 2014a. Tendentsii za podobriavane na boino prilojnata podgotovka na voennoslujeshtite ot slujba "Voenna policia", Sport and science, izv. (1), $114-118$.

Yordanov, S. 2014b. Znachenie, sashtnost I miasto na sporta policheiska lichna zashtita, Sport and science, izv. (1), 129 - 133.

Yordanov, S., 2015. Izsledvane mnenieto na voennite politsai kam fizicheskata podgotovka I obushenieto po boino prilojni tehniki. Nauchni trudove na $R U$, 54, $97-100$.

Kachev, O., 2015. Dinamika na razvitie na psihomotorikata pri studenti obuchavani po lichna zashtita. Nauchni trudove na RU, 54, 52 - 57.

Panayotov, V., 2018. Muscles, bodybuilding, fitness and strength training.

Panayotov, V., Yankova, N. \& Slavova, V., 2018. Fizicheska podgotovka na studenti v magistarska programa "Sport I sigurnost" kam NSA "V. Levski", Sbornik dokladi ot Petata mevdunarodna nauchna konferencia Sport I sigurnost 21-22 may 2018, $67-70$.

Slavova, V., 2017. Smeseno obuchenie. Principles, approaches and practices, Sofia: Avangard Pres.

Yankova, N., 2016. Occurrence and development of weightlifting for women in Bulgaria, Ed. Car Ins, Sofia.

Yoni Petrovska

https://orcid.org/0000-0003-3401-2029

Department Heavy Athletics, Boxing, Fencing and Sport for All

National Sports Academy "Vassil Levski"

1700 Sofia, Bulgaria

E-mail: bersh4444@gmail.com 